\title{
CYMBIDIUM SIGMOIDEUM (ORCHIDACEAE), A NEW ADDITION TO THE FLORA OF THE PHILIPPINES
}

\author{
Mark Arcebal K. Naive ${ }^{1,4}$, Jade Ann Grace P. Dalisay ${ }^{2}$ \& Porferio S. Bangcaya ${ }^{3}$ \\ ${ }^{1}$ Department of Biological Sciences, College of Science and Mathematics, Mindanao State University- \\ Iligan Institute of Technology, Andres Bonifacio Ave, Iligan City, 9200 Lanao del Norte, Philippines \\ ${ }^{2}$ College of Teacher Education, Biological Science Department, University of Antique, \\ Tario-Lim Memorial Campus, 5707 Antique, Philippines \\ ${ }^{3}$ Office of the Campus Administrator, University of Antique, Libertad Extension Campus, Libertad, \\ Antique 5711, Philippines \\ ${ }^{4}$ Corresponding author: arciinaive19@gmail.com
}

\begin{abstract}
Cymbidium sigmoideum (Orchidaceae: Epidendroideae) is reported here as a new record for the Philippines based on the collection from Antique Province on the island of Panay. A detailed description and photographs are provided for easy identification of the species. With this discovery, the Philippines now holds a total of 13 species and three subspecies of Cymbidium.

Key Words / Palabras clave: Antique, biodiversity, Cymbidieae, Malesian flora, Panay Island, new record, taxonomy
\end{abstract}

Introduction. Described by Olof Swartz in 1799, Cymbidium belongs to the tribe Cymbidieae and is one of the most attractive and desirable orchid genera in the world because of its showy and fragrant flowers (Mandal et al. 2018). According to the current taxonomy (Du Puy \& Cribb 2007, Govaerts et al. 2020), it includes 74 species, four subspecies, 10 varieties and 15 natural hybrids widely distributed in South and East Asia, north to Japan and south through the Malay Archipelago and New Guinea to northern and eastern Australia. In the Philippines, the genus is represented by 12 species and three subspecies (Cootes 2011, Pelser et al. 2011).

An unidentified flowering Cymbidium specimen was collected during the second and third author's botanical exploration in one of the tropical mountains of Antique Province of Panay island in the Philippines last May 2019. After examination of its morphology and comparison with protologues and the relevant literature as well as digitized type specimens of the genus Cymbidium from the Philippines and neighbouring countries, a match was made with Cymbidium sigmoideum J.J.Sm.

Cymbidium sigmoideum was first discovered in central Sumatra in 1905 by Wilhelm Micholitz who sent his specimens to the nursery of Sander, who sent one to
Kew for identification. However, Rolfe (the first curator of orchid herbarium at the Royal Botanic Gardens, Kew) failed to recognize it as a new species (Du Puy \& Cribb 2007). J.J. Smith (1907) later described it based on a collection of Connell from Java. The species was previously known to occur only in Java, Sumatra and Borneo (Du Puy \& Cribb 2007). Thus, this paper reports its first record in the Philippines. The species is presented here with a description and photographs to aid accurate identification.

Materials and methods. The measurement and description of the species were based on examinations of photographic images of plants in situ, living specimens, and voucher herbarium specimens held at the University of Santo Tomas Herbarium (USTH). The description follows the recent work of Zhang et al. (2018) with general plant descriptive terminologies following Beentje (2016). Flowers have been preserved in $70 \%$ ethyl alcohol for microscopic study. Available type specimens of Cymbidium spp. from the Philippines and neighbouring countries were examined in different herbaria (viz. B, BM, E, GH, K, KATH, L, LINN, M, P, SBT, SING) through high resolution images accessed at https://plants. jstor.org/. 


\section{TAXONOMIC TREATMENT}

Cymbidium sigmoideum J.J.Sm., Bull. Dép. Agric. Indes Néerl. 13: 52, 1907. ECyperorchis sigmoidea (J.J.Sm.) J.J.Sm., Bull. Jard. Bot. Buitenzorg, sér. 3, 9: 57, 1927. TYPE: Java Loemadjang, Connell s.n. (holotype BO!). Fig. 1.

Cymbidium kinabaluense K.M.Wong \& C.L.Chan, Sandakania, 2: 86. 1993. TYPE: Sabah, Mt. Kinabalu, C.L. Chan \& Jamili Nais s.n. (holotype $\mathrm{SAN}$; isotype: $\mathrm{SRN}$ ).

Perennial, epiphytic herb. Pseudobulbs inconspicuous, $4.2-4.8 \mathrm{~cm}$ long by $2.0-2.3 \mathrm{~cm}$ in diameter, with 5-7 leaves. Leaves $38.0-43.5 \mathrm{~cm}$ long by $0.8-$ $1.2 \mathrm{~cm}$ wide, linear-obovate, glabrous both sides, margin entire, apex acute. Inflorescence up to 47 $\mathrm{cm}$ long, arising from the base of the pseudobulb; peduncle horizontal to pendulous, green, covered by overlapping sheaths; sheaths 5-6, boat-shaped, 8.5$9.0 \mathrm{~cm}$ long, cucullate, yellowish brown to brown, apex acute to subacuminate; rachis $10-20 \mathrm{~cm}$ long, bearing 4-6 flowers, green, glabrous; floral bracts 2-3 mm long, ovate, hyaline green, glabrous, apex acute. Flower $3.0-3.5 \mathrm{~cm}$ across, waxy; Pedicel and ovary $2.0-2.5 \mathrm{~cm}$ long, green, terete, glabrous. Dorsal sepal $2.5-2.8 \mathrm{~cm}$ long by $0.8-1.0 \mathrm{~cm}$ wide, narrowly obovate, glabrous, concave, closely covering the column, green with dark or purple-brown spots and stain, margin entire, apex acute, porrect. Lateral sepals $2.5-2.8 \mathrm{~cm}$ long by $0.8-1.0 \mathrm{~cm}$ wide, falcate, glabrous, spreading or reflexed, green with dark or purple-brown spots and stain, margin entire, apex acute. Petals $2.1-2.4 \mathrm{~cm}$ long by $0.5 \mathrm{~cm}$ wide, falcate, glabrous, spreading in the apical half, green with dark or purple-brown spots and stain, margin entire, apex acute. Lip 3-lobed, green with dark or purple-brown spots and stain, fused with base of the column for 5 $\mathrm{mm}$, with a glabrous disc (callus) with two slightly raised ridges and a swollen rounded apex; sidelobes 5-6 mm broad, broadly triangular, fleshy, erect and clasping the column, minutely papillose, apex subacute; mid-lobe small, 7-9 mm long by 2.0-2.3 $\mathrm{mm}$ wide, ligulate, glabrous, strongly recurved or coiled, apex acute. Column broad, about $2 \mathrm{~cm}$ long,
S-shaped, glabrous, yellowish green with purplish red spots, basal quarter fused to the base of the labellum; anther cap and viscidium elongated into a projecting rostellum; pollinia about $2 \mathrm{~mm}$ long, quadrangularpyriform, cleft. Fruit not seen.

Distribution: Java, Sumatra, Borneo (Sabah) and the Philippines (Antique). This species warrants further observation and collection to determine whether there are other known populations present in other areas within the Philippine archipelago.

НАвітAт: Found growing on trunks and large branches of trees which are covered by moss cushions in deeply shaded mossy forest at elevations between 1500 to $1600 \mathrm{~m}$ above sea level.

Phenology: Observed flowering in the wild in May (this study). According to Du Puy \& Cribb (2007), this species flowers all throughout the year.

Conservation status: Vu A1cd; B1ab (Du Puy \& Cribb 2007).

Specimen examined: PHILIPPINES, Visayas, Antique, elev. 1520 m, 10 May 2019, JAGP Dalisay \& PS Bangcaya 102 (USTH). - Full locality data are withheld to prevent potential exploitation of wild populations for commercial purposes.

Cymbidium sigmoideum is a species belonging to the section Cyperorchis (Blume) P.F.Hunt, characterized by the fusion at the base of the lip and column, two cleft pollinia, narrow petals, porrect dorsal sepal covering the column and quadrangularpyriform pollinia. According to Du Puy \& Cribb (2007), it closely resembles $C$. roseum J.J.Sm. from Java and C. whiteae King \& Pantl. from Sikkim. However, C. sigmoideum differs in having shiny brown spotted, green flowers, narrow falcate petals, narrow, ligulate, recurved midlobe and S-shaped column.

A number of characters shows greater variation based on our recent material than the original given by J.J. Smith. For example, the leaves are smaller (38-43.5 cm long $v s$. up to $102 \mathrm{~cm}$ long), colour of the pedicel and ovary (green $v s$. purple) and dimensions

Right, Figure 1. Cymbidium sigmoideum J.J.Sm. A. Habit. B. Flowers (front view). C. Flower (profile view). D. Dissected flower (ds: dorsal sepal, scale bar: $2 \mathrm{~cm}$; 1s: lateral sepals, scale bar: $2 \mathrm{~cm}$; p: petals, scale bar: $2 \mathrm{~cm}$; 1: labellum; c: column, scale bar: $2 \mathrm{~cm})$. Photos by: JAGP Dalisay. 


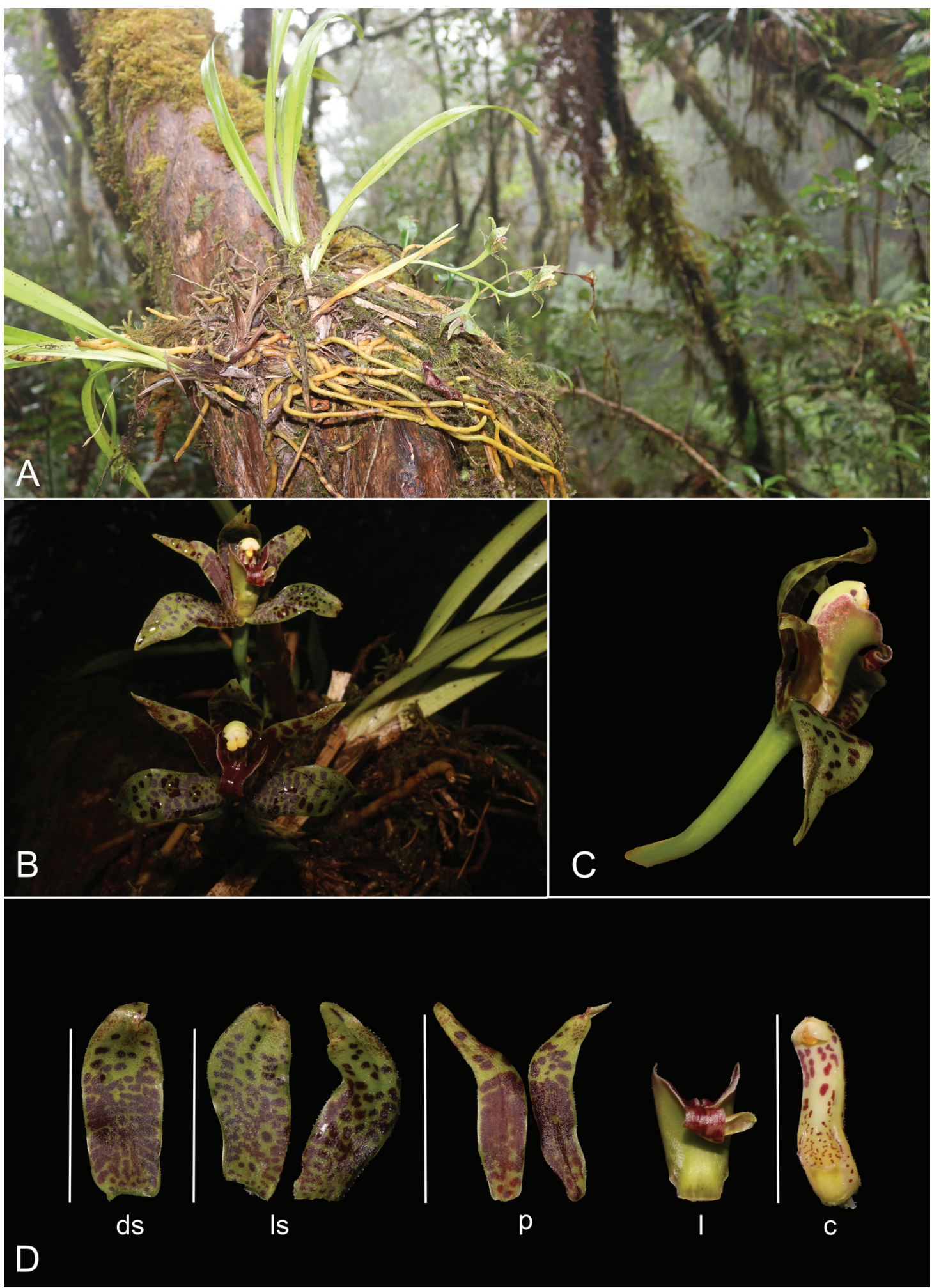


of other parts which can be explained by the stage of development of the inflorescence, growth conditions and processing techniques. Despite these differences, we are in no doubt that our recent collection is $C$. sigmoideum.
Acknowledgements. We thank Mecan Rod Celesio, Helvzen Junvy Vego, Samuel O. Tamolin and Michael O. Tamolin for the assistance during fieldwork; Paul Ormerod and André Schuiteman for verifying the identity of the species; and Department of Environment and Natural Resources-City Environment \& Natural Resources office (DENR-CENRO) Culasi for allowing us to conduct this study.

\section{Literature Cited}

Beentje, H. (2016). The Kew Plant Glossary, an illustrated dictionary of plant terms. Second ed. Kew, Richmond: Kew Publishing, Royal Botanic Gardens. $184 \mathrm{pp}$.

Cootes, J. (2011). Philippine native orchid species. Quezon City: Katha Publishing Co. 289 pp.

Du Puy, D. J. \& Cribb P. J. (2007). The genus Cymbidium. Kew, Richmond: Royal Botanic Garden. 359 pp.

Govaerts, R. J., Bernet, P., Kratochvil, K., Gerlach, G., Carr, G., Alrich, P., Pridgeon, A. M., Pfahl, J., Campacci, M. A., Holland Baptista, D., Trigges, H., Shaw, J., Cribb, P., George, A., Kreuz, K. \& Wood, J. (2020). World Checklist of Orchidaceae. The Board of Trustees of the Royal Botanic Gardens, Kew. Retrieved from http://wcsp.science.kew.org/ [Accessed on 2 January 2020].

Mandal, K. K., Khora, S. S. \& Kar, T. (2018). Cymbidium macrorhizon (Orchidaceae): A new record for the Flora of Odisha, India. Annals of Plant Sciences, 7(9), 2415-2417.

Pelser, P. B., Barcelona, J. F. \& Nickrent, D. L. (Eds). (2011). Co's Digital Flora of the Philippines. Retrieved from: http:// www.philippineplants.org [Accessed on 28 December 2019].

Smith, J. J. (1907). Die Orchideen Von Java. Bulletin de Département de l'Agriculture aux Indes Néerlandaises, 13, 52.

Zhang, G. Q., Chen, G. Z., Liu, Z. J. \& Lan, S. R. (2018). Cymbidium daweishanense (Orchidaceae; Epidendroideae), a new species from China: evidence from morphological and molecular analyses. Phytotaxa, 374(3), 249-256. 